\title{
PENDIDIKAN KARAKTER; GARANSI PERADABAN BERKEMAJUAN
}

\section{Ilham Muchtar ${ }^{1}$}

\author{
${ }^{* 1}$ Pendidikan Agama Islam Fakultas Agama Islam| Unismuh Makassar
}

\begin{abstract}
ABSTRAK
Pendidikan berkarakter moral adalah kunci untuk perbaikan sosial dan kemajuan peradaban bangsa yang menjunjung tinggi integritas nilai dan kemanusiaan. Bangunan sebuah peradaban sesungguhnya terletak pada manusia-manusianya. Manusialah yang membangun sebuah peradaban. Manusia pula yang mempertahankan dan menjadikannya tetap hidup, bukan bangunan atau struktur fisiknya. Kehancuran dan kemundurannya pun demikian. Maka, sejatinya pendidikan karakter disebut efektif apabila telah mencapai tujuan untuk menjadikan manusia yang mempunyai karakter; kemampuan sosial (social skill), pengembangan kepribadian (personal improvement) dan pemecahan masalah secara komprehensif (comprehensive problem solving). Manusiamanusia seperti ini hanya bisa lahir dari sistem pendidikan yang Islami yang tidak hanya mendidik akal dan keterampilan, tetapi juga mendidik jiwa. Konsep inilah yang akan menjadi garansi peradaban berkemajuan.
\end{abstract}

Kata Kunci: Karakter, Social Skill, Improvement, problem solving

\begin{abstract}
Moral Character Education is key to social improvement and nation of progress civilization that uphold the integrity and humanity. The real building civilization based on their human. Human build a civilization. Human also hold and keep it alive, not the building or stucture physical. Its destruction and decline are so. Then, Character education is actually effective when it has achieved the goal to make people who have the character; social skill, personal improvement and comprehensive problem solving. The human like this can only be born from an Islamic educational system that not only educate mind and skill, but also educate the soul. This concept will be the Guaranty of Progress Civilization.
\end{abstract}

Keywords: Character, Social Skill, Improvement, Problem Solving 


\section{PENDAHULUAN}

Dunia memang sedang mencari keseimbangan. Ditengah maraknya fenomena perilaku amoral yang melibatkan peserta didik sebagai pelakunya, seperti seks pra-nikah, video porno, penyalahgunaan NAPZA dan minuman keras, tawuran, kekerasan perploncoan, penghinaan guru dan sesama murid melalui facebook. Bahkan kasuskasus korupsi, kolusi dan manipulasi yang prevalensinya banyak melibatkan orangorang terdidik dan terpelajar. Hal ini menjadi tamparan keras bagi dunia pendidikan yang idealnya melahirkan generasi-generasi terdidik dan beretika sekaligus menjadi musuh utama fenomena-fenomena perilaku amoral tersebut.

Mungkin hal inilah yang menjadi kekhawatiran para tokoh-tokoh dunia, seperti Mahatma Gandhi yang memperingatkan tentang salah satu tujuh dosa fatal, yaitu "education without character"(pendidikan tanpa karakter). Begitu pula, Dr. Martin Luther King yang pernah berkata: "Intelligence plus character...that is the goal of true education" (Kecerdasan plus karakter....itu adalah tujuan akhir dari pendidikan sebenarnya). Juga Theodore Roosevelt yang mengatakan: "To educate a person in mind and not in morals is to educate a menace to society" (Mendidik seseorang dalam aspek kecerdasan otak dan bukan aspek moral adalah ancaman mara-bahaya kepada masyarakat). Bahkan pendidikan yang menghasilkan manusia berkarakter ini telah lama didengungdengungkan oleh pandita pendidikan Indonesia, Ki Hajar Dewantara, dengan pendidikan yang berpilar kepada Cipta, Rasa dan Karsa. Bermakna bahwa pendidikan bukan sekedar memberikan pengetahuan (knowledge) tetapi juga mengasah afeksi moral sehingga menghasilkan karya bagi kepentingan ummat manusia.

Berdasarkan latar belakang fenomena dan pendapat para tokoh inilah, dunia pendidikan saat ini mencoba mengevaluasi sistem pembelajarannya untuk menghasilkan manusia berkarakter. Proses pencarian jati diri sistem pendidikan, khususnya di Indonesia inilah yang merupakan arah untuk mencapai keseimbangan atau kondisi homeostatic yang relatif sebagaimana setiap manusia mempunyai keinginan untuk mencapainya. Di sinilah peran sekolah dan guru sebagai institusi pendidikan formal sebagai posisi yang 'tertantang' dalam menghadapi fenomena yang 
berkaitan dengan globalisasi dan degradasi moral.

\section{METODE PENELITIAN}

Metode yang digunakan dalam penelitian ini adalah metode deskriptif kualitatif. Penelitian deskriptif merupakan penelitian yang bertujuan menggambarkan suatu kondisi terkait. Adapun sumber data dari tulisan ini adalah buku-buku ilmiah yang diterbitkan dengan maksud dijadikan sumber referensi

\section{HASIL DAN PEMBAHASAN PENELITIAN}

\section{Defenisi Pendidikan Karakter}

Secara etimologis, istilah karakter berasal dari bahasa Yunani, yaitu kharaseein, yang awalnya mengandung arti mengukir tanda di kertas atau lilin yang berfungsi sebagai pembeda (Bohlin, 2005). Istilah ini selanjutnya lebih merujuk secara umum pada bentuk khas yang membedakan sesuatu dengan yang lainnya. Dengan demikian, karakter dapat juga menunjukkan sekumpulan kualitas atau karakteristik yang dapat digunakan untuk membedakan diri seseorang dengan orang lain (Timpe, 2007).
Perkembangan berikutnya, pengetahuan tentang karakter banyak dipelajari pada ilmu-ilmu sosial. Dalam filsafat misalnya, istilah karakter biasa digunakan untuk merujuk dimensi moral seseorang. Salah satu contoh adalah ilmuwan Aristoteles yang sering menggunakan istilah ethē untuk karakter yang secara etimologis berkaitan dengan "ethics" dan "morality". Adapun ahli psikologi pun banyak yang mengajukan definisi karakter dari berbagai pendekatan. Ada yang menggunakan istilah karakter pada area moral saja, ada juga yang memakainya pada domain moral dan nonmoral.

Menurut Hasting et al. (2007), karakter mempunyai domain moral dan nonmoral. Karakter berdomain moral ialah semua perilaku yang merujuk kepada hubungan interpersonal atau hubungan dengan orang lain. Contohnya, kasih sayang, empati, loyal, membantu dan peduli dengan orang lain (sifat-sifat feminis). Sedangkan karakter berdomain nonmoral adalah semua perilaku yang merujuk kepada pengembangan sifat-sifat dalam diri atau intrapersonal. Contohnya, disiplin, jujur, bertanggung jawab, pantang menyerah dan percaya diri (sifatsifat maskulin). Baik karakter berdomain moral maupun nonmoral tersebut 
mempunyai tujuan yang sama, yaitu untuk membentuk kepribadian yang peka terhadap kepentingan sosial (prososial).

Karakter juga terkadang dipandang sebagai kepribadian dan/atau lebih bersifat perilaku. Banyak ilmuwan psikologi yang mengabaikan fungsi kognitif pada definisi mereka mengenai karakter, namun ada juga yang lebih bersifat komprehensif. Bahkan ada ilmuwan yang menyatakan bahwa karakter merupakan suatu konstruksi sosial. Menurut ahli konstruksi sosial, karakter seseorang dipengaruhi oleh lingkungan sosialnya. Hal ini akan dijelaskan lebih lanjut dalam perkembangan moral pada manusia.

Salah satu definisi karakter yang cukup lugas dikemukakan oleh Berkowitz (2002), yaitu sekumpulan karakteristik psikologis individu yang mempengaruhi kemampuan seseorang dan membantu dirinya untuk dapat berfungsi secara moral. Dikarenakan sifat karakter yang plural, maka beberapa ahli pun membagi karakter itu ke dalam beberapa kategori. Peterson dan Seligman (2004) mengklasifikasikan kekuatan karakter menjadi 6 kelompok besar yang kemudian menurunkan 24 karakter, yaitu kognitif (wisdom and knowledge), emosional (courage/kesatriaan), interpersonal (humanity), hidup bersama (justice), menghadapi dan mengatasi hal-hal yang tak menyenangkan (temperance), dan spiritual (transcendence). Di Indonesia, sebuah lembaga yang bernama Indonesia Heritage Foundation merumuskan nilainilai yang patut diajarkan kepada anakanak untuk menjadikannya pribadi berkarakter. Megawangi menamakannya "9 Pilar Karakter", yakni cinta Tuhan dan kebenaran; bertanggung jawab, kedisiplinan, dan mandiri; mempunyai amanah; bersikap hormat dan santun; mempunyai rasa kasih sayang, kepedulian, dan mampu kerja sama; percaya diri, kreatif, dan pantang menyerah; mempunyai rasa keadilan dan sikap kepemimpinan; baik dan rendah hati; mempunyai toleransi dan cinta damai.

\section{Urgensi Pendidikan Karakter}

Pendidikan berkarakter moral adalah kunci untuk perbaikan sosial dan kemajuan peradaban bangsa yang menjunjung tinggi integritas nilai dan kemanusiaan. Harapan dari pendidikan berkarakter moral adalah tercapainya keseimbangan antara pengetahuan dan moral. Salah satu pendekatan dalam pendidikan berkarakter moral ialah dengan pendidikan moral agama yang diterapkan dalam setiap kehidupan 
akademis. Jika pengetahuan dan moral agama dapat diintegrasikan maka berkembanglah kesempurnaan ilmu berlandaskan moralitas (excellent with morality). "Ilmu tanpa agama akan buta, agama tanpa ilmu akan lumpuh."

Pendidikan berkarakter moral dikatakan efektif apabila telah mencapai tujuan untuk menjadikan manusia yang mempunyai karakter; kemampuan sosial (social skill), pengembangan kepribadian (personal improvement) dan pemecahan masalah secara komprehensif (comprehensive problem solving).

Pendidikan berkarakter moral memerlukan figur teladan sebagai role model untuk menegakkan nilai atau aturan yang telah disepakati bersama. Di sinilah peran pendidik, khususnya guru, orang tua, masyarakat dan pemerintah sebagai figur teladan agar peserta didik mampu melakukan imitasi terhadap perilaku moral. Oleh karena semua pihak dituntut untuk terlibat aktif maka perlu adanya sinergisitas diantara elemen tersebut sehingga pendidikan berkarakter moral dapat terus dilakukan secara berkelanjutan. Sinergi semua elemen inilah yang mengingatkan kita kepada kata-kata bijak, "Tidak ada keberhasilan individu, yang ada adalah keberhasilan kolektif."

\section{Kriteria Peradaban Berkemajuan}

Peradaban berasal dari kata bahasa Arab, yaitu 'adab', yang artinya kebaikan yang sempurna dan menyeluruh, baik itu spiritual maupun material. Syed Naquib al-Attas, penggagas Islamisasi ilmu dari Malaysia, memaknai orang beradab sebagai berikut, Orang yang beradab adalah, orang yang menyadari sepenuhnya tanggung jawab dirinya kepada Tuhan; yang memahami dan menunaikan keadilan terhadap dirinya sendiri dan orang lain dalam masyarakatnya; yang terus berupaya meningkatkan setiap aspek dalam dirinya menuju kesempurnaan sebagai manusia yang beradab.

Walaupun berasal dari bahasa Arab, namun orang-orang Arab (Islam) menerjemahkan istilah peradaban sebagai Tamaddun. Istilah ini berasal dari kata daya-na yang bermakna hutang. Dr. Hamid Fahmy, pendiri INSIST (Institute for The Study of Islamic Thought and Civilization), menjelaskan bahwa konsep tamaddun, tak bisa dilepaskan dari din (agama), sebab ia berasal dari akar kata yang sama. Maka dalam Islam, peradaban lahir dari agama dan merupakan konsekuensi dari keberhutangan manusia kepada Allah swt yang telah 
menganugerahkan segala nikmat kepadanya.

Dari dua makna di atas, kita dapat menyimpulkan bahwa peradaban adalah segala sesuatu yang lahir dan hidup dari cara pandang serta budaya orang-orang yang beradab, sebagai konsekuensi dari keberhutangan mereka kepada Tuhannya. Artinya, peradaban tidak bisa dilepaskan dari keberagamaan orang-orangnya. Ia lahir dan tumbuh dalam cakupan maknanya.

Peradaban Islam tidak bisa dilepaskan dari konsep din dan ibadah kepada Allah swt. Begitu pula peradaban lain, ia tidak bisa dilepaskan dari konsep agama dan peribadatannya. Peradaban Romawi tidak bisa lepas dari kristennya. Peradaban Mesir kuno tak bisa dilepaskan dari paganisme (penyembahan terhadap tuhan-tuhan buatan). Peradaban India tak bisa dilepaskan dari agama Hindu, dan lain-lain.

Pada Hakekatnya, peradaban berkemajuan selalu berkaitan dengan maju mundurnya budaya keilmuan. Kemajuan yang dicapai Barat saat ini tak lepas dari budaya ilmu yang berkembang lebih dahulu. Penemuan-penemuan baru dalam bidang ilmu pengetahuan dan teknologi telah mengantarkan Barat kepada dominasi di segala bidang.
Bahkan, penjajahan kepada berbagai negara di asia dan afrika merupakan kelanjutan dari penemuan-penemuan itu. Kemajuan ilmu pengetahuan membutuhkan sokongan dana yang sangat kuat melalui sumber daya alam yang kaya. Dan sumber daya alam itu tidak dimiliki Barat. Maka selain tujuan politik dan ekonomi, pengembangan ilmu pengetahuan menjadi salah satu alasan Barat menjajah negara-negara lain.

Pendidikan Karakter, Sebagai Jaminan Kemajuan suatu bangsa tidak diukur dari struktur fisik yang berhasil didirikan. Sebab struktur fisik hanyalah produk dari sebuah peradaban. Ia bukanlah hakekat dari peradaban itu sendiri. Kita bisa melihat negara-negara Arab yang saat ini memiliki bangunanbangunan fisik yang sangat megah dan menakjubkan, tetapi mereka tidak dikenal sebagai negara yang memiliki peradaban yang maju. Sebab bangunan-bangunan fisik itu tidak dibangun dari tradisi ilmu pengetahuan dan kebudayaan yang mereka miliki. Mereka hanya membelinya dengan sumber daya alam minyak yang sangat berlimpah di bumi mereka. Kita pun bisa melihat peradaban Romawi yang sekarang tinggal puing-puing sejarah saja. Meski bangunan fisiknya yang megah itu 
masih bisa kita lihat, namun ia hanyalah puing-puing tak bernyawa. Ia tak memiliki pancaran kehidupan lagi. Ibarat raga yang sudah kehilangan ruhnya.

Sebagaimana dibahas sebelumnya, peradaban Islam tidak bisa dilepaskan dari konsep ibadah kepada Allah swt. Maka, ia lahir dari ajaran-ajaran yang tertuang dalam al-Quran dan Sunnah Rasulullah saw. Kemajuan dan kemundurannya tak lepas dari hubungan atau interaksi kaum muslimin dengan keduanya. Jika ingin maju, berpeganglah kepada keduanya. Jika mundur, itu artinya kaum muslimin telah meninggalkan keduanya. Hal ini sesuai dengan wasiat Rasulullah saw dalam khutbah wada di Arafah, "Hai manusia, sesungguhnya aku telah tinggalkan untuk kalian dua hal yang jika kamu berpegang kepada keduanya, kamu tidak akan tersesat selamanya: Kitab Allah dan Sunnah Nabi-Nya”. (HR. al-Hakim)

Syakib Arselan dalam buku 'limadza taakharal muslimun wa taqaddama ghairuhum' (mengapa umat Islam mundur dan yang lainnya maju), menyimpulkan bahwa orang-orang Barat maju karena mereka meninggalkan agama, sedangkan umat Islam maju apabila mereka berpegang kepada agamanya. Jelaslah kiranya, apabila umat
Islam ingin maju, ia harus kembali kepada ajaran Islam.

Namun, kondisi umat Islam yang saat ini tertinggal dari negara Barat, sungguh jauh berbeda dengan keadaan ideal yang seharusnya dicapai. Dalam bidang ilmu pengetahuan dan capaiancapaian teknologi, umat Islam cukup jauh tertinggal. Begitu pula dalam bidangbidang yang lainnya. Umat Islam saat ini gagal membangun sebuah peradaban yang maju. Padahal dahulu umat Islam pernah berhasil mendirikan bangunan peradaban yang teramat kokoh dan megah, bahkan tidak mampu diikuti oleh umat mana pun saat itu. Kondisi ini tentu harus dicari jalan keluarnya.

Sesungguhnya Islam telah memberikan pondasi yang teramat kokoh untuk meraih kemajuan tersebut. Ayat yang pertama kali Allah swt turunkan, secara langsung memerintahkan kepada umat manusia untuk membaca. Belum lagi jika kita lihat ayat-ayat lain yang secara tegas mengingatkan manusia untuk menghindari kebodohan dan mendorong untuk mencari ilmu. Kalimat-kalimat seperti 'mengapa kamu tidak berpikir, mengapa kamu tidak mempergunakan akal, dan lain-lain' sering kita dapati dalam al-Quran. Di dalam hadits pun seperti itu. Rasulullah saw menyebutkan 
bahwa menuntut ilmu hukumnya wajib bagi setiap muslim (HR. Ibnu Majah). Dengan pondasi ini, seharusnya umat Islam mampu membangun peradaban yang sangat maju. Namun kenyataan tak seindah harapan.

Untuk membangun sistem pendidikan yang berkarakter Islami ini diperlukan perhatian dari seluruh umat Islam. Sebab sistem pendidikan ini tidak akan meraih keberhasilan yang diinginkan jika tidak didukung oleh unsur-unsur sekelilingnya. Sebaik apa pun sistem pendidikan, jika kondisi masyarakat tidak mendukung akan membuat beberapa bagiannya rapuh. Dan bagian yang rapuh ini akan menyebabkan rusaknya bagian yang lain. Oleh karena itu, dukungan lingkungan dan seluruh komponen masyarakat sangat dibutuhkan, demi tercapainya bangunan peradaban yang berkemajuan.

\section{KESIMPULAN}

Karakter mempunyai domain moral dan nonmoral. Karakter berdomain moral ialah semua perilaku yang merujuk kepada hubungan interpersonal atau hubungan dengan orang lain. Seperti, kasih sayang, empati, loyal, membantu dan peduli dengan orang lain (sifat-sifat feminis). Sedangkan karakter berdomain nonmoral adalah semua perilaku yang merujuk kepada pengembangan sifat-sifat dalam diri atau intrapersonal. Seperti, disiplin, jujur, bertanggung jawab, pantang menyerah dan percaya diri (sifatsifat maskulin). Baik karakter berdomain moral maupun nonmoral tersebut mempunyai tujuan yang sama, yaitu untuk membentuk kepribadian yang peka terhadap kepentingan sosial (prososial)

1. Pendidikan berkarakter moral adalah kunci untuk perbaikan sosial dan kemajuan peradaban bangsa yang menjunjung tinggi integritas nilai dan kemanusiaan. Harapan dari pendidikan berkarakter moral adalah tercapainya keseimbangan antara pengetahuan dan moral. Salah satu pendekatan dalam pendidikan berkarakter moral ialah dengan pendidikan moral agama.

2. Bangunan sebuah peradaban sesungguhnya terletak pada manusia-manusianya. Manusialah yang membangun sebuah peradaban. Manusia pula yang mempertahankan dan menjadikannya tetap hidup, bukan bangunan atau struktur fisiknya. Kehancuran dan kemundurannya pun demikian. Ia disebabkan oleh ketidakmampuan manusia- 
manusianya untuk menjaga peradabannya.

3. Manusia-manusia berperadaban maju ini hanya bisa lahir dari sistem pendidikan yang Islami. Sistem pendidikan yang berdiri di atas pondasi Tauhid yang kokoh dan tak lekang oleh waktu. Sistem pendidikan yang tidak memisahkan dirinya dari agama. Sistem pendidikan yang tidak hanya mendidik akal dan keterampilan, tetapi juga mendidik jiwa. Demikianlah konsep pendidikan karakter yang akan menjadi solusi peradaban berkemajuan.

\section{DAFTAR PUSTAKA}

Abdul Latif Tibawi, Arabic and Islamic Themes: Historical, Educational and Literary Studies (London: Luzac \& Co., 1974).

Abdullah Idi \& Toto Suharto, Revitalisasi Pendidikan Islam, Tiara Wacana, Yogyakarta, 2006.

Abdurrohman Mas'ud, Menggagas Format Pendidikan Nondikotomik (Humanisme Religius sebagai Paradigma Pendidikan Islam), Gama Media, Yogyakarta, 2002.

Abu Nu'aym, Ahmad ibn 'Abd Allah alAsbahani (d.430 A.H.) Hilyat alAuliya', 10 jilid, Mesir: al-Sa'adah Press, 1357, 1/339.
Al-Mawdudi, The Process of Islamic Revolution, (Lahore, 1967) hal. $14,41$.

Asma Hasan Fahmi, Sejarah dan Filsafat Pendidikan Islam, alih bahasa Ibrahim Husein, Jakarta, Bulan Bintang, 1979.

Azyumardi Azra, Pendidikan Islam, Tradisi dan Moderniasasi menuju Millenium Baru, Jakarta, Logos, 1999.

Charles Michael Stanton, Pendidikan Tinggi dalam Islam Sejarah dan Peranannya dalam kemajuan ilmu pengatahuan, Logos Publising House, Jakarta, 1994.

Ibnu Khaldun, 'Abd al-Rahman Ibn MuÍammad, The Muqaddimah: an Introduction to history, Penerjemah Franz Rosenthal, 3 jilid, editor N.J. Dawood. London, Routledge \& Kegan Paul, 1978.

M. Athiyah Al Abrosyi, Dasar-Dasar Pokok Pendidikan Islam, alih bahasa Bustami A. Ghani dan Djohar Bahry, Jakarta, Bulan Bintang, 1993.

Muhaimin, Paradigma Pendidikan Islam Upaya mengefektifkan Pendidikan Agama Islam di Sekolah, Bandung, PT. Remaja Rosdakarya, 2008.

Nurcholis Madjid, Kaki Langit Peradaban Islam, Jakarta, Paramadina, 1997.

Shaykh Ohif al-Zayn, al-Islam wa Idulujiyyat al-Insan, Beirut, Dar al- Kitab al-Lubnani, 1989. 